\title{
Developing micro-level urban ecosystem indicators for sustainability assessment
}

\author{
Didem Dizdaroglu \\ School of Urban Design and Landscape Architecture, Bilkent University, Universiteler Mh., 06800 Ankara, Turkey
}

\section{A R T I C L E I N F O}

\section{Article history:}

Received 14 September 2014

Received in revised form 12 June 2015

Accepted 12 June 2015

Available online $\mathrm{xxxx}$

\section{Keywords:}

Sustainability assessment

Urban ecosystem indicators

Micro-level

Spatial analysis

\begin{abstract}
A B S T R A C T
Sustainability assessment is increasingly being viewed as an important tool to aid in the shift towards sustainable urban ecosystems. An urban ecosystem is a dynamic system and requires regular monitoring and assessment through a set of relevant indicators. An indicator is a parameter which provides information about the state of the environment by producing a quantitative value. Indicator-based sustainability assessment needs to be considered on all spatial scales to provide efficient information of urban ecosystem sustainability. The detailed data is necessary to assess environmental change in urban ecosystems at local scale and easily transfer this information to the national and global scales. This paper proposes a set of key micro-level urban ecosystem indicators for monitoring the sustainability of residential developments. The proposed indicator framework measures the sustainability performance of urban ecosystem in 3 main categories including: natural environment, built environment, and socio-economic environment which are made up of 9 sub-categories, consisting of 23 indicators. This paper also describes theoretical foundations for the selection of each indicator with reference to the literature.
\end{abstract}

(C) 2015 Elsevier Inc. All rights reserved.

\section{Introduction}

According to Guidotti (2010), urban ecosystems are basically complicated blends of artificial and natural ecological systems, where people built their settlements on the remnants of natural ecosystems and form a complex structure that mimics their functions. A sustainable urban ecosystem is defined by Newman and Jennings (2008, p. 108) as "ecosystems which are ethical, effective (healthy and equitable), zero-waste, self-regulating, resilient, self-renewing, flexible, psychologically-fulfilling and cooperative". The sustainability of urban ecosystem depends on balanced interaction between human activities and natural resources by applying sustainable development principles, which can be summarized as follows:

- Sustainable land use and urban design through: (1) improving the quality of life by providing social interactions and easier access to a wide range of services; (2) minimizing energy consumption via green building design technologies; (3) reducing greenhouse gas emissions by providing less auto-dependent development, and; (4) creating environmentally sensitive areas to restore park and greenway systems (Williams et al., 2000; Coplak and Raksanyi, 2003; Wheeler, 2004; Jabareen, 2006).

- Sustainable transportation through promoting energy-efficient and environmentally friendly transport options, via: (1) providing and maintaining bike paths and bicycle lanes; (2) improving

\footnotetext{
E-mail address: dizdaroglu@bilkent.edu.tr.
}

pedestrian ways and their connectivity; (3) promoting accessibility of public transport, and; (4) reducing traffic road usage demand via implementing congestion pricing, road use or parking charges, vehicle taxes (Drumheller et al., 2001; Coplak and Raksanyi, 2003; Wheeler, 2004; Jabareen, 2006; AASHTO, 2010).

- Environmental protection and restoration through protecting the existing species, habitats and ecosystems in the city by creating ecologically valuable green spaces: (1) gardens; (2) parks; (3) green alleys; (4) green roofs, and; (5) green buffer zones, such as green belts, green wedges, green ways, green fingers (Coplak and Raksanyi, 2003; Jabareen, 2006; Convery et al., 2008).

- Renewable energy and waste management is essential for developing sustainable urban ecosystems. Renewable energy technologies can be summarized as: (1) hydropower; (2) biomass energy; (3) geothermal energy; (4) wind power; (5) solar energy, and; (6) photovoltaic technologies (Strong, 1999). Another approach is waste management practices: (1) landfill; (2) incineration; (3) biological treatment; (4) zero waste; (5) recycling-orientated eco-industrial parks, and; (6) environmental taxes, law and policies (Davidson, 2011).

- Creating a sustainable economy promotes: (1) clean technologies (i.e., Silicon Valley in California); (2) renewable energy sources; (3) green business and job initiatives; (4) green tax policies; (5) green infrastructure, and; (6) walkable, mixed-use and transit-oriented real estate developments (Nixon, 2009).

- Environmental justice and social equity through protecting public health and welfare by managing natural resources in an equitable manner. The strategies for creating well-balanced, integrated and socially 
equal communities are: (1) increasing affordable housing; (2) providing efficient transportation and easier access to public amenities; (3) promoting local economic growth through increased job opportunities; (4) providing environmental quality and protection, and; (5) improving community participation into decision-making processes (Agyeman and Evans, 2003; Wheeler, 2004).

In recent years, cities have been working to create sustainable urban ecosystems through new initiatives such as Adelaide 'Christie Walk EcoVillage’ Project; Kawasaki ‘Eco Town' Program; Johannesburg ‘GreenHouse People's Environmental Centre' Project; 'Melbourne Principles' for Sustainable Cities by the United Nations Environment Program; Freiburg Green City; the 'Hannover Principles' by William McDonough and Michael Braungart; 'One Planet Living Framework' by BioRegional Development Group and World Wildlife Fund. By looking at these practices, it is necessary to regulate the natural processes and control the scale of human activities; therefore, sustainability assessment needs to be integrated into the planning process. This integration is important in terms of understanding the physical characteristics of urban settlements as well as recognising their potential, limitations and risks in the planning process (Lein, 2003). In this context, sustainability assessment provides a fundamental approach to the efficient use of natural resources while adapting human activities in a less harmful way to the environment (Clini et al., 2008).

There is a wide variety of sustainability assessment tools, among them; composite indicators have a role in the reporting of progress towards sustainable development by providing information about the environmental performance, efforts to influence that performance, or the condition of the environment (Warhurst, 2002). As the impacts of environmental problems have multi-scale characteristics, assessment needs to be considered on all scales to provide efficient information of urban ecosystem sustainability. The detailed micro-level data is necessary to assess local environmental change in urban ecosystems by identifying the hotspots of unsustainability and to provide insights into the national and global scales. The main objective of this paper is to recommend key microlevel urban ecosystem indicators for monitoring the sustainability of urban development. The paper is structured as follows. Section 1 provides an introduction to the concept of urban ecosystems by establishing principles for the management of their sustainability. Section 2 discusses sustainability assessment by underlining the role of indicators to assess environmental change in urban ecosystems. Section 3 describes urban ecosystem indicators by introducing a review of international sustainability indicator initiatives. Section 4 proposes a new indicator framework for micro-level sustainability assessment by describing theoretical foundations for the selection of each indicator with reference to the literature. The proposed set of indicators, excluding socio-economic category due to limited budget and time schedule, was used in the calculation of the Micro-level Urban-ecosystem Sustainability IndeX (MUSIX) by applying in a case study investigation in the Gold Coast City, Queensland, Australia (please refer to Dizdaroglu and Yigitcanlar, 2014 for more information). Finally, Section 5 summarizes and concludes the paper.

\section{Sustainability assessment using indicators}

Sustainability assessment is: "a generic term for a methodology that aims to assist decision making by identifying, measuring and comparing the social, economic and environmental implications of a project, program, or policy option" (DSE, 2007, p.1). According to Guijt and Moiseev (2001), the main uses of sustainability assessment are providing: (1) an input to strategic planning and decision-making for governments, international and non-governmental organisations; (2) information for monitoring, evaluation and impact analysis; (3) a source for reporting on international conventions, state of the environment reporting and on specific themes, and; (4) a process to raise awareness about sustainable development issues. There are three general categorization of sustainability assessment including indicators/indices, integrated assessment and product-related assessment tools (Ness et al., 2007). These tools are arranged on a time continuum based on if they are retrospective (indicators/indices), prospective (integrated assessment) or both (product-related assessment). The first category consists of indicators/indices. An indicator is a variable which describes one characteristic of the state of a system through observed or estimated data. An index is a quantitative aggregation of many indicators which provides a simplified, coherent, multidimensional view of a system (Mayer, 2008). Indicators/indices are used to monitor the long-term sustainability trends from a retrospective point of view. The information they provide helps in making short-term projections and relevant decisions for the future. The second category consists of integrated assessment tools which investigate policy change or project implementation through developing scenarios. Examples of this category are: (1) Multi-Criteria Analysis is used in the comparison of policy options, by identifying the effects of these options, their relative performance and the trade-offs to be made (Hirst et al., 2012); (2) Cost Benefit Anal$y$ sis is used for evaluating public or private investment proposals by weighing the costs of the project against the expected benefits, and; (3) Impact assessment is a group of forecasting tools used for improving the basis for policymaking and project approval process. For instance, Environmental Impact Assessment and Strategic Environmental Assessment are commonly used examples for assessing the environmental impacts of development projects or strategic decisions in order to reduce their potential externalities (Partidario, 1999; Sadler, 1999). The third category consists of product-related assessment tools focusing on the material and energy flows of a product or service from a life cycle perspective. These tools allow both retrospective and prospective assessments that support decision-making. The most established example is the Life Cycle Assessment, which evaluates resource use, and resulting environmental impacts of a product throughout its lifecycle and the outputs influence environmental policies and regulations. Product Material Flow Analysis and Product Energy Analysis are other examples of this category.

As one of them, indicator-based sustainability assessment is increasingly recognized as a useful tool which contributes to the planning process by: (1) indicating the state of local sustainability; (2) making sustainability measurable and therefore manageable; (3) providing feedback on the progress during the implementation stage of sustainable development, and; (3) representing the advantages and disadvantages of different development alternatives to help finding win-win situations (Ciegis et al., 2009). Urban ecosystem indicators play an important role in successfully achieving urban sustainability. In this context, selecting relevant indicators is necessary to monitor the implementation of sustainability policies and provide feedbacks needed to accomplish the desirable state of sustainable urban development (Shen et al., 2011). According to Kellaway and Lukacs (2000), a good indicator is a measure of one or more ecological factors that reflects the overall health and sustainability of an ecosystem. Key urban ecosystem indicators should be able to (NZOSA, 2014):

- Be valid and meaningful: It should reflect the phenomenon it is intended to measure and is appropriate to the needs of the user,

- Be sensitive and specific to the underlying phenomenon: It should respond relatively quickly and noticeably to changes,

- Be statistically sound: Indicator measurement needs to be methodologically sound and fit for the purpose to which it is being applied,

- Be intelligible: It should be sufficiently simple to be interpreted in practice,

- Allow international comparison: It needs to reflect local policy goals/ objectives, but also needs to be consistent with other international indicator programs to allow comparisons across countries,

- Be consistent over time: The usefulness of indicators is related directly to the ability to track trends over time, 
- Be timely: Data needs to be collected and reported regularly and frequently, relative to the phenomena being monitored, and;

- Be linked with policy or emerging issues: It should be selected to reflect the important and emerging issues as closely as possible.

In sum, sustainability assessment is an important part of the planning process in terms of visualising and measuring progress in our efforts to move towards urban sustainability. In order to provide quantitative results there is a need for specific measures for sustainability assessment. Indicator frameworks provide a comprehensive understanding of what the concept of sustainability encompasses how to measure it through incorporating the key dimensions, potential indicator sets, and their linkages ( Wu and Wu, 2012).

\section{Urban ecosystem indicators}

As defined by Newton et al. (1998, p. 8), "urban ecosystem indicators are physical, chemical, biological or socio-economic measures that best represent the key elements of a complex ecosystem or environmental issue". They reflect environmental changes over a period of time and provide information about the interrelationship between environment and human activities by underlining emerging environmental, social and economic issues. Urban ecosystem indicators are categorized in several different ways. The World Resources Institute divided indicators into four categories based on the human and environment interactions (Hammond et al., 1995; Alberti, 1996): (1) Source indicators, for measuring the depletion of resources and the degradation of biological systems (i.e. agriculture, forest, marine resources); (2) Sink indicators, for evaluating the capacity of resources to absorb emissions and waste (i.e., climate change, acidification, toxification); (3) Life Support indicators, for monitoring the change in the state of the Earth's ecosystems and biodiversity (i.e., threatened species, special lands, oceans), and; (4) Human impact indicators, for measuring the impacts of environmental problems on public health and the quality of life (i.e., housing, waste, health, natural disaster). According to Bakkes et al. (1994), indicators are classified in three ways: (1) classification by use assists to investigate the same environmental problem with different indicator sets depending on the environmental policy or scientific development; (2) classification by subject or theme (i.e., climate change and energy consumption) assist to investigate particular political issues, and; (3) classification by position in causality chains such as environmental pressures, environmental status and societal responses. The World Bank (1997) also identified three major types of indicators: (1) Individual indicator sets, which include large lists of indicators covering a wide range of issues to improve the integration of environmental concerns into policies (i.e., the OECD indicators); (2) Thematic indicators, which include a small set of indicators to evaluate environmental policy for each of the issues (i.e., World Development indicators), and; (3) Systemic indicators, which include one indicator to identify a complex problem (i.e., the wealth and genuine savings indicators).

In recent years, an increasing number of urban ecosystem indicator initiatives have been developed by international organisations. A widely used framework the "Driving force-Pressure-State-Impact-Response (DPSIR)" developed by the Organisation for Economic Cooperation and Development has provided a basis for other initiatives, including United Nations Commission on Sustainable Development Theme Indicator Framework, United Nations Centre for Human Settlements Indicators, Millennium Development Goal Indicators, European Environment Agency list of core indicators, World Health Organisation Healthy Cities Indicators, and, Rio to Johannesburg Dashboard of Sustainability. Furthermore, several countries have developed indicator initiatives to achieve sustainable cities (e.g., Sustainable Calgary, Victoria Community Indicators Project, London Quality of Life Indicators, Sustainable Seattle, Sustainable Chattanooga, and Sustainable Community Roundtable of South Puget Sound). In addition, there are number of initiatives working on developing sustainability indices which is basically an aggregation of different indicators under a well-developed and pre-determined methodology (e.g., Human Development Index, City Development Index, Environmental Sustainability Index, Environmental Performance Index, Environmental Vulnerability Index, Well-being Index, Living Planet Index, Ecological Footprint, and Index of Sustainable Economic Welfare).

As can be seen from the aforementioned examples, they are concerned only with larger geographical units. They evaluate environmental impacts at the macro-levels from national to regional and international scales. Although they are promising, these studies report multiple barriers in terms of data availability during the indicator development process, which raised the issue of missing data treatments. For instance, in the Environmental Sustainability Index, a number of indicators including wetland protection, the quality of solid and hazardous waste management, exposure to heavy metals and toxics, and ecosystem functionality are excluded due to a lack of adequate data to measure them across in a number of countries (Emerson et al., 2010). Due to lack of comparable data, countries including Marshall Islands, Monaco, Nauru, Korea, San Marino, Somalia, South Sudan and Tuvalu have been omitted in the calculation of Human Development Index (UNDP, 2005). The lack of reliable data for some environmental policy areas including waste management, recycling and removal; impacts of toxic chemicals and heavy metals; $\mathrm{SO}_{2}$ emissions and acid rain; soil erosion and soil productivity, and; ecosystem problems (e.g. loss of wetlands and fragmented human settlements) has put constraints on the calculation of the Environmental Performance Index (Kraemer and Peichert, 2007). The conclusion can be drawn from this discussion that the major problem in sustainability assessment lies in the gathering of reliable and accessible data. This implies availability of micro-level data as a key criterion for providing useful information in the comparison of different countries (Kulig et al., 2010). Further research is required to develop more effective approaches and solutions supporting the measurable and accessible data for the indicator development as well as capable of performing a comparative assessment via indicators at micro-level so as to aggregate these assessment findings to national and international levels.

\section{A micro-level indicator framework for sustainable urban ecosystem assessment}

To develop scientifically sound urban ecosystem indicators it is necessary to formulate a theoretical framework that serves as a starting point for the selection of relevant indicators and data sets. The theoretical framework of the proposed parcel-scale indicator set is based on the definition of sustainable city. As defined by Hoornweg and Freire (2013), sustainable cities are urban communities that are committed to improving the well-being of current and future residents; they integrate economic, environmental, and social considerations. Cities which are considered to be sustainable are those which have strong economic growth, are socially inclusive in their growth, and are environmentally responsible (i.e. have a positive or at least minimal adverse impact on the environment). The inter-linkages among the three pillars of sustainable development are evident in cities, which function as integrated systems (Hirst et al., 2012).

The city as a place "where nature and artifice meet" (Levi-Strauss, 1961), is a dynamic organism composed of people, built-up environment and infrastructure which are highly dependent on nature. To examine the interaction between urban development and environmental change we need to consider cities as heterogeneous ecosystems with their natural and built environments whose interactions are characterized by socio-economic settings within urban areas. In this sense, an urban ecosystem comprises: (1) natural environment (i.e., topographical features, flora/fauna, soil, water); (2) built environment (i.e., buildings, roads, bridges and other infrastructure), and (3) socio-economic environment (i.e., demographic structure 
Table 1

Theoretical framework for the indicator selection.

\begin{tabular}{|c|c|c|c|c|}
\hline Aims & Goals & Categories & Indicators & Contribution to sustainability \\
\hline \multirow{4}{*}{$\begin{array}{l}\text { Ecological resilience of } \\
\text { natural environment }\end{array}$} & $\begin{array}{l}\text { Hydrological } \\
\text { conservation }\end{array}$ & Hydrology & $\begin{array}{l}\text { Impervious } \\
\text { surface ratio } \\
\text { Surface runoff }\end{array}$ & $\begin{array}{l}\text { Impervious surfaces play an important role on urban hydrology and stormwater } \\
\text { management. Built and paved surfaces impede rainwater infiltration and groundwater } \\
\text { recharge that leads to increased stormwater runoff and pollutant load carried by } \\
\text { stormwater into the waterways. The high volume and velocity caused by stormwater runoff } \\
\text { increases the risk of flooding and erosion by destroying aquatic and riparian habitats. }\end{array}$ \\
\hline & $\begin{array}{l}\text { Urban heat island } \\
\text { mitigation }\end{array}$ & Microclimate & Green area ratio & $\begin{array}{l}\text { Alteration of vegetated surfaces to impervious surfaces results in increased land surface } \\
\text { temperatures that affects absorption of solar radiation, storage of heat and causes } \\
\text { temperature difference between urban and rural areas which is called the urban heat island } \\
\text { effect. }\end{array}$ \\
\hline & $\begin{array}{l}\text { Environmental } \\
\text { quality }\end{array}$ & Pollution & $\begin{array}{l}\text { Air pollution } \\
\text { Stormwater } \\
\text { pollution } \\
\text { Noise pollution }\end{array}$ & $\begin{array}{l}\text { Land cover change results in the form of air pollutant emissions from transport activity and } \\
\text { noise pollution emitted by transportation systems. Noise pollution affects human health by } \\
\text { causing psychological symptoms. Pollutants produced by transportation activities are } \\
\text { carried into waterways by stormwater, and this increased amount of pollutants leads to the } \\
\text { physical degradation of urban streams. }\end{array}$ \\
\hline & $\begin{array}{l}\text { Sustainable } \\
\text { mobility \& } \\
\text { accessibility }\end{array}$ & Location & $\begin{array}{l}\text { Proximity to land } \\
\text { use destinations } \\
\text { Access to public } \\
\text { transport stops } \\
\text { Sidewalk design }\end{array}$ & $\begin{array}{l}\text { As a consequence of rapid urbanisation, distances between housing, jobs and other land use } \\
\text { destinations have increased. Dispersed land use patterns are usually designed for motor } \\
\text { vehicle transport, which causes increased consumption of non-renewable resources and } \\
\text { traffic congestion. Auto-oriented development faces a number of challenges such as heavy } \\
\text { and high vehicle traffic, poor pathways blocked by parked cars, disconnected street systems } \\
\text { and unsecure street environments. }\end{array}$ \\
\hline \multirow[t]{3}{*}{$\begin{array}{l}\text { Sustainable } \\
\text { development of built } \\
\text { environment }\end{array}$} & $\begin{array}{l}\text { Sustainable urban } \\
\text { design }\end{array}$ & Design & Landscape design & $\begin{array}{l}\text { Buildings have significant environmental impacts on natural resources through their } \\
\text { construction, operation and demolition phases. Also, there are many significant effects of } \\
\text { buildings on the microclimatic conditions through building location, orientation, design, } \\
\text { material form, types and colors. These effects can be summarized as: higher level of } \\
\text { temperatures, humidity, rainfall, air pressure, wind speeds and energy usage. }\end{array}$ \\
\hline & $\begin{array}{l}\text { Use of renewable } \\
\text { resources }\end{array}$ & Efficiency & $\begin{array}{l}\text { Energy } \\
\text { conservation } \\
\text { Renewable } \\
\text { energy }\end{array}$ & $\begin{array}{l}\text { Private households make significant contributions to sustainability in terms of resource } \\
\text { consumption. As impervious surfaces collect solar heat in their dense mass, they raise air } \\
\text { temperatures which lead to increased energy consumption resulting from the lighting, } \\
\text { heating, cooling of the buildings and water consumption. }\end{array}$ \\
\hline & $\begin{array}{l}\text { Environmental } \\
\text { awareness }\end{array}$ & $\begin{array}{l}\text { Demographic } \\
\text { characteristics }\end{array}$ & $\begin{array}{l}\text { Household type } \\
\text { Age } \\
\text { Immigration } \\
\text { status }\end{array}$ & $\begin{array}{l}\text { A number of studies (Lenzen et al., 2004; Ferrer-i-Carbonell and Van Den Bergh, 2004; Barr } \\
\text { and Gilg, 2006; Jensen, 2008; Kerkhof et al., 2009; Caeiro et al., 2012) have discussed the } \\
\text { connection between socio-economic characteristics of households and their consumption } \\
\text { patterns. Additionally, Luck et al. (2009) found that immigrants are generally less familiar }\end{array}$ \\
\hline \multirow[t]{3}{*}{$\begin{array}{l}\text { Socially \& economically } \\
\text { sustainable } \\
\text { community }\end{array}$} & Social equity & $\begin{array}{l}\text { Social } \\
\text { stratification }\end{array}$ & $\begin{array}{l}\text { Equivalized } \\
\text { household } \\
\text { income } \\
\text { Employment } \\
\text { status } \\
\text { Level of } \\
\text { education }\end{array}$ & $\begin{array}{l}\text { with the local environment and land management practices than native residents. Troy } \\
\text { et al. (2007) found a positive relationship between education level and the level of } \\
\text { knowledge of land management and environmentally sensitive behaviors. Researchers have } \\
\text { found that lifestyle behavior is an important predictor of consumption patterns. The } \\
\text { Baltimore Ecosystem Study proposed the term "ecology of prestige" refers to the } \\
\text { phenomenon in which household patterns of consumption and expenditure on } \\
\text { environmentally relevant goods and services are motivated by group identity and }\end{array}$ \\
\hline & \multirow{2}{*}{$\begin{array}{l}\text { Sustainable } \\
\text { households }\end{array}$} & \multirow{2}{*}{ Lifestyle } & $\begin{array}{l}\text { Car ownership } \\
\text { Home ownership }\end{array}$ & $\begin{array}{l}\text { perceptions of social status associated with different lifestyles. This theory suggests that a } \\
\text { households' land management decisions are influenced by its desire to uphold the prestige }\end{array}$ \\
\hline & & & & $\begin{array}{l}\text { of its community and outwardly express its membership in a given lifestyle group (Grove } \\
\text { et al, 2006). }\end{array}$ \\
\hline
\end{tabular}

of the users within the area, economic activities, employment structure, regulations and policies). Thereby, they constitute a basis for the selection of indicator categories and indicators (Table 1).

The indicator set was developed by a comprehensive review of existing indicator initiatives (e.g., UNCSD, 2001; OECD, 2003; EEA, 2005; Japan Sustainable Building Consortium, 2007; SEDAC, 2007; U.S. Green Building Council, 2008, 2009). Indicators need to be chosen carefully so that they reflect the environmental issues and measure the sustainability performance of the area effectively. As a result of the subjective nature of indicator selection, expert survey allows experts from various backgrounds - that are familiar with local conditions, environmental needs and policy priorities - to agree on a consensus view of the relative importance of the indicators based on their experience and judgment. Expert judgment has been used in a number of studies, including Environmental Performance Index (Esty et al., 2006), Environmental Sustainability Index (ESI, 2005), Eco-indicator 99 (Pre Consultants, 2004), E-Business Readiness Index (Pennoni et al., 2005), Urban Sustainability Index (Zhang, 2002), and Index of Environmental Friendliness (Puolamaa et al., 1996). In this study, a total of 21 experts comprising academics, planners, engineers and architects were chosen for survey, through purposive sampling of the project's industry partners. In order to allow comparison, it is desirable to standardize the data for all the indicators by conducting numerous methodologies such as: standardisation (or z-scores), min-max, distance to a reference, indicators above or below the mean (OECD, 2008). According to the theoretical framework and the data properties, benchmarking normalisation was employed to remove the scale effects of different indicator units. By reviewing various studies in the literature, benchmark values for each indicator were assigned according to their minimum and maximum impacts on urban sustainability. Each indicator is expressed with a score ranging between 1 and 5 indicating (Carraro et al., 2009): (1) Low (extremely unsustainable situation); (2) Medium-Low (not sustainable but not as severely as in the previous level); (3) Medium (a discrete level of sustainability); (4) Medium-High (satisfactory level of sustainability but not on target), and; (5) High (target level of sustainability). It has to be mentioned that this normalisation method is only implemented for the natural and built environment categories of indicators. Data on the indicators related to socio-economic structure of the urban ecosystem were generated by household surveys. The data was collected using a questionnaire survey with the households living in the area. Telephone or face to face interviews were conducted with the participant by special trained interviewers. In case of privacy concerns, alternative methods might be selected. The proposed micro-level indicator framework measures the sustainability performance of urban ecosystem in 3 main categories which are made up of 9 sub-categories, consisting of 23 indicators, presented in Appendix A. 


\section{Concluding remarks}

As defined by Olalla-Tarraga (2006), a city is an ecological black hole which is depleting natural resources and productivity beyond its boundaries and an urban sustainability appraisal is necessary for the assessment of these implications. Urban ecosystem indicators can be considered as a powerful tool for evaluating the impacts of urban development on the environment and society and making political decisions for achieving sustainability. When selected carefully and used appropriately, they simplify and summarize enormous flows of information by providing quantitative data, and; develop useful feedback mechanisms by highlighting urban hotspots (Ciegis et al., 2009). Indicator selection is often subjective and there is no silver bullet solution that helps to choose the best indicator, therefore, the choice of an indicator depends on factors such as whether they are cost-effective, easy to understand, scientifically reliable and internationally comparable (Agol et al., 2014). According to the North West Regional Assembly (2003), an effective indicator framework needs to take into account the following basic criteria: (1) policy relevance and utility for users, (2) analytical soundness, and; (3) measurability. However, because of data unavailability, it is difficult to produce indicators which meet all these requirements. In recent years, numerous organisations have developed sustainable development indicator frameworks at a wide range of geographical units including neighborhood, city, region, and country. However, most of them raise important challenges in terms of measurement due to poor data availability at different scales. Scale of data collection is considered as a critical step in developing an indicator framework. The interpretability power of the assessment depends on the quality of detailed data. From the above arguments, it is obvious that an indicator framework has to capture critical issues at the micro-level to provide a comprehensive picture of sustainable development at the meso- and macrolevels.

The proposed indicator set can be used for benchmarking sustainability performance at the micro-level and that it also serves as a tool for different stakeholders in establishing sustainable development policies in many ways: (1) It helps master planned communities and developers to rate the sustainability of their development which can also be linked to other sustainability rating systems such as BREEAM, LEED, Green Star, and CASBEE; (2) It assists local governments to detect environmentally problematic areas in the existing settlements, thereby; this information can be used to improve the future development of infrastructure and services, and; (3) It increases the awareness of individual residents on the environmental issues and the findings can be used to encourage them to make sustainable improvements in their own parcels. Finally, the proposed indicator set focuses on sustainability assessment of the residential developments by collecting data in a micro-level spatial unit and provides a conceptual basis for the policy recommendations and strategies for achieving sustainable cities. The studies in the literature show that there is a lack of consistent data sources within and between communities (Kraemer and Peichert, 2007; Mayer, 2008; Singh et al., 2009; Mori and Christodoulou 2011; Emerson et al., 2010). Therefore, the development of sustainability indicators requires further investigation and more micro-level indicators are needed to be developed to work with more detailed data in sustainability assessments.

\section{Acknowledgments}

This paper is an outcome of an Australian Research Council Linkage Project (ARCLP0882637), jointly funded by the Commonwealth Government of Australia, Gold Coast City Council, Queensland Transport and Main Roads, and Queensland University of Technology (QUT). The author wishes to acknowledge the contribution of the project partners, research team and expert panel members.

\section{Appendix A. Supplementary data}

Supplementary data to this article can be found online at http://dx. doi.org/10.1016/j.eiar.2015.06.004.

\section{References}

AASHTO, 2010. International Scan: Reducing Congestion \& Funding Transportation Using Road Pricing. American Association of State Highway and Transportation Officials with the Federal Highway Administration and the National Cooperative Highway Research Program, Washington, DC.

Agol, D., Latawiec, A.E., Strassburg, B.B.N., 2014. Evaluating impacts of development and conservation projects using sustainability indicators: opportunities and challenges. Environ. Impact Assess. Rev. 48, 1-9.

Agyeman, J., Evans, T., 2003. Toward just sustainability in urban communities: building equity rights with sustainable solutions. Ann. Am. Acad. Pol. Soc. Sci. 590, 35-53.

Alberti, M., 1996. Measuring urban sustainability. Environ. Impact Assess. Rev. 16, $381-424$.

Bakkes, J.A., van den Born, G.J., Helder, J.C., Swart, R.J., Hope, C.W., Parker, J.D.E., 1994. An Overview of Environmental Indicators: State of the Art and Perspectives, Report No UNEP/EATR94-01RIVM/402001001.

Barr, S., Gilg, A., 2006. Sustainable lifestyles: framing environmental action in and around the home. Geoforum 37 (6), 906-920.

Carraro, C., Ciampalini, F., Cruciani, C., Giove, S., Lanzi, E., 2009. The FEEM Sustainability Index (FEEM SI) Methodological Report. Retrieved April 15, 2012, from www. feemsi.org.

Caeiro, S., Ramos, T., Husingh, D., 2012. A conceptual model for the development and evaluation of household sustainable consumption indicators. J. Clean. Prod. 27, 72-91.

Ciegis, R., Ramanauskiene, J., Startiene, G., 2009. Theoretical reasoning of the use of indicators and indices for sustainable development assessment. Inzinerine Ekonomika (Engineering Economics) 3, 33-40.

Clini, C., Musu, I., Gullino, M.L., 2008. Sustainable Development and Environmental Management Experiences and Case Studies. Springer, Dordrecht, The Netherlands.

Convery, S., Carey, T., Clabby, G., Brennan, C., 2008. Green City Guidelines: Advice for the Protection and Enhancement of Biodiversity in Medium to High-Density Urban Developments. Retrieved March 08, 2012, from http://www.uep.ie/pdfs/guidelines_ intro.pdf.

Coplak, J., Raksanyi, P., 2003. Ecocity: Planning Sustainable Settlements. Slovak University of Technology, Bratislava.

Davidson, G., 2011. Waste Management Practices: Literature Review. Retrieved April 14, 2012, from http://www.dal.ca/content/dam/dalhousie/pdf/sustainability/Waste\% 20Management\%20Literature\%20Review\%20Final\%20June\%202011\%20(1.49\%20MB). pdf.

Dizdaroglu, D., Yigitcanlar, T., 2014. A parcel-scale assessment tool to measure sustainability through urban ecosystem components: the MUSIX model. Ecol. Indic. 41, $115-130$.

Drumheller, B., Quaid, A., Wyman, M., Liljenwall, J., Young, A., 2001. Sustainable Transportation Options for Protecting the Climate, a Guide for Local Governments, International Council for Local Environmental Initiatives USA.

DSE, 2007. Method for Conducting a Sustainability Assessment of Future Management Options for State Forests Supplying Water to Melbourne. Department of Sustainability and Environment, Victoria.

EEA, 2005. EEA Core Set of Indicators Guide, Technical Report: No. 1/2005 Copenhagen.

Emerson, J., Esty, D.C., Levy, M.A., Kim, C.H., Mara, V., Sherbinin, A., et al., 2010. 2010 Environmental Performance Index. Yale Centre for Environmental Law and Policy, New Haven.

ESI, 2005. 2005 Environmental Sustainability Index Appendix A Methodology. Yale Center for Environmental Law \& Policy, Center for International Earth Science Information Network Columbia University, New Haven.

Esty, D.C., Levy, M.A., Srebotnjak, T., de Sherbinin, A., Kim, C.H., Anderson, B., 2006. Pilot Environmental Performance Index. Yale Center for Environmental Law \& Policy, New Haven.

Ferrer-i-Carbonell, A., Van Den Bergh, J., 2004. A micro-econometric analysis of determinants of unsustainable consumption in The Netherlands. Environ. Resour. Econ. 27, 367-389.

Grove, J.M., Cadenasso, M., Burch Jr., W.R., Pickett, S.T.A., O'Neil-Dunne, J.P.M., Schwarz, K., Wilson, M., Troy, A.R., Boone, C., 2006. Data and methods comparing social structure and vegetation structure of urban neighborhoods in Baltimore, Maryland. Soc. Nat. Resour. 19, 117-136.

Guidotti, T.L., 2010. Health and urban ecosystems. Arch. Environ. Occup. Health 65 (1), 54-55.

Guijt, I., Moiseev, A., 2001. Resource Kit for Sustainability Assessment. IUCN (International Union for Conservation of Nature and Natural Resources), Gland, Switzerland and Cambridge, UK.

Hammond, A., Adriaanse, A., Rodenburg, E., Bryant, D., Woodward, R., 1995. Environmental Indicators: A Systematic Approach to Measuring and Reporting on Environmental Policy Performance in the Context of Sustainable Development. World Resources Institute, Washington, DC.

Hirst, P., et al., 2012. Joint European Support for Sustainable Investment in City Areas. European Investment Bank Retrieved February 17, 2015, from http://ec.europa.eu/ regional_policy/thefunds/instruments/doc/jessica/jessica_horizontal_study_smart_ and_sustainable_cities_en.pdf.

Hoornweg, D., Freire, M., 2013. Building Sustainability in an Urbanizing World: A Data Compendium for the World's 100 Largest Urban Areas. World Bank, Washington, DC. 
Jabareen, Y.R., 2006. Sustainable urban forms: their typologies, models, and concepts. J. Plan. Educ. Res. 26, 38-52.

Japan Sustainable Building Consortium, 2007. CASBEE (Comprehensive Assessment System for Building Environmental Efficiency) for Home and Urban Development Technical Manual. Retrieved August 17, 2010, from http://www.ibec.or.jp/CASBEE/ english/.

Jensen, J.O., 2008. Measuring consumption in households: interpretations and strategies. Ecol. Econ. 68 (1-2), 353-361.

Kellaway, D., Lukacs, G., 2000. Scoping report: ecological sustainability guideline for waterways. ACTFR Report No. 00/12. Australian Centre for Tropical Freshwater Research, James Cook University, QLD.

Kerkhof, A.C., Nonhebel, S., Moll, H.C., 2009. Relating the environmental impact of consumption to household expenditures: an input-output analysis. Ecol. Econ. 68, 1160-1170.

Kraemer, R.A., Peichert, H., 2007. Analysis of the Yale Environmental Performance Index (EPI). UBA-Texte 09/08. German Federal Environment Agency, Dessau.

Kulig, A., Kolfoort, H., Hoekstra, R., 2010. The case for the hybrid capital approach for the measurement of the welfare and sustainability. Ecol. Indic. 10, 118-128.

Lein, J.M., 2003. Integrated Environmental Planning. Blackwell Science, Oxford, United Kingdom.

Lenzen, M., Dey, C., Foran, B., 2004. Energy requirements of Sydney households. Ecol. Econ. 49 (3), 375-399.

Levi-Strauss, C., 1961. Tristes Tropiques, Translated by John Russell. Criterion Books, New York.

Luck, G.W., Smallbone, L.T., O'Brien, R., 2009. Socio-economics and vegetation change in urban ecosystems: patterns in space and time. Ecosystems 12, 604-620.

Mayer, A.L., 2008. Strengths and weaknesses of common sustainability indices for multidimensional systems. Environ. Int. 34 (1), 277-291.

Mori, K., Christodoulou, A., 2011. Review of sustainability indices and indicators: towards a new City Sustainability Index (CSI). Environ. Impact Assess. Rev. 32 (1), 94-106.

Ness, B., Urbel-Piirsalu, E., Anderberg, S., Olsson, L., 2007. Categorising tools for assessing sustainability. Ecol. Econ. 60 (3), 498-508.

Newman, P., Jennings, I., 2008. Cities as Sustainable Ecosystems: Principles and Practices. Island Press, Washington, DC.

Newton, P., Flood, J., Berry, M., Bhatia, K., Brown, S., Cabelli, A. et al. (1998). Environmental Indicators for National State of the Environment Reporting - Human Settlements, Australia: State of the Environment (Environmental Indicator Reports), Department of the Environment, Canberra.

Nixon, J., 2009. Sustainable Economic Development: Initiatives, Programs, and Strategies for Cities and Regions. Urban Sustainability Associates (USA).

North West Regional Assembly, 2003. A communications framework for sustainability indicators. Technical Report. Manchester University.

NZOSA, 2014. Criteria for Indicator Selection. New Zealand's Official Statistics Agency Retrieved June 08, 2014, from http://www.stats.govt.nz/methods/indicator-guidelines/ criteria-for-indicator-selection.aspx.

OECD, 2003. Environmental Indicators: Development, Measurement and Use Reference Paper. OECD, Paris.

OECD, 2008. Handbook on Constructing Composite Indicators: Methodology and User Guide Paris.

Olalla-Tarraga, M.A., 2006. A conceptual framework to assess sustainability in urban ecological systems. International Journal of Sustainable Development \& World Ecology $13(1), 1-15$.

Partidario, M.R., 1999. Strategic environmental assessment principles and potential. In: Petts, J. (Ed.), Handbook of Environmental Impact Assessment. Environmental Impact Assessment: Process, Methods and Potential 1. Blackwell Science, Oxford, pp. 60-73.

Pennoni, F., Tarantola, S., Latvala, A., 2005. The 2005 European e-Business Readiness Index.
Pre Consultants, 2004. The Eco-Indicator 99-A Damage Oriented Method for Life Cycle Assessment Methodology Report.

Puolamaa, M., Kaplas, M., Reinikainen, T., 1996. Index of Environmental Friendliness, A Methodological Study. Eurostat.

Sadler, B., 1999. Framework for environmental sustainability assessment and assurance. In: Petts, J. (Ed.), Handbook of Environmental Impact Assessment. Environmental Impact Assessment: Process, Methods and Potential 1. Blackwell Science, Oxford pp. 12-32.

SEDAC, 2007. Compendium of Environmental Sustainability Indicators. The Socioeconomic Data and Applications Center (SEDAC), Center for International Earth Science Information Network (CIESIN), Columbia University, USA Retrieved June 06, 2009, from http://sedac.ciesin.columbia.edu/es/compendium.html.

Shen, L.Y., Ochoa, J.J., Shah, M.N., Zhang, X., 2011. The application of urban sustainability indicators-a comparison between various practices. Habitat Int 35, 17-29.

Singh, R.K., Murty, H.R., Gupta, S.K., Dikshit, A.K., 2009. An overview of sustainability assessment methodologies. Ecol. Indic. 9 (1), 189-212.

Strong, S.J., 1999. Introduction to renewable energy technologies. In: Kilbert, C.J. (Ed.), Reshaping the Built Environment: Ecology, Ethics and Economics. Island Press, Washington, DC, pp. 89-116.

The World Bank (1997). Expanding the measure of wealth: indicators of environmentally sustainable development, Environmentally Sustainable Development Studies and Monographs Series No. 17

Troy, A.R., Grove, J.M., O'Neil-Dunne, J.P.M., Cadenasso, M., Pickett, S.T.A., 2007. Predicting opportunities for greening and patterns of vegetation on private urban lands. Environ. Manage. 40, 394-412.

U.S. Green Building Council, 2008. LEED (Leadership in Environmental and Energy Design) for Homes Rating System. Retrieved October 06, 2009, from http://www. usgbc.org/.

U.S. Green Building Council, 2009. LEED (Leadership in Environmental and Energy Design) for Neighbourhood Development. Retrieved October 06, 2009, from http:// www.usgbc.org/.

UNCSD, 2001. Indicators of Sustainable Development: Guidelines and Methodologies United Nations, New York.

UNDP (United Nations Development Programme), 2005. Human Development Report 2005. Oxford University Press, Oxford.

Warhurst, A., 2002. Sustainability Indicators and Sustainability Performance Management Mining Missals and Sustainable Development Project, Report No. 43. World Business Council for Sustainable Development, International Institute for Environmental and Development, Warnick, UK.

Wheeler, S.M., 2004. Planning for Sustainability: Creating Livable, Equitable, and Ecological Communities. Routledge, NY.

Williams, K., Burton, E., Jenks, M., 2000. Achieving Sustainable Urban Form. Routledge London.

Wu, J., Wu, T., 2012. Sustainability indicators and indices. Handbook of Sustainable Management. Imperial College Press, London.

Zhang, M., 2002. Measuring Urban Sustainability in China. Thela Thesis, Amsterdam.

Didem Dizdaroglu is an Assistant Professor at the School of Urban Design and Landscape Architecture, Bilkent University, Ankara, Turkey. She received her Ph.D. degree from Queensland University of Technology, Brisbane, Australia. The Ph.D. thesis focused on developing a new parcel-level sustainability assessment tool with the use of ArcGIS and SPSS software to assist in the decision-making for policy-officers and planners to investigate the impacts of urban development on ecosystems and come up with effective environmental policies for sustainable urban development. Her Ph.D. study received the QUT Outstanding Doctoral Thesis Award 2013. Her research interests include sustainable urban ecosystems, urban sustainability assessment using geospatial analysis, sustainability indicators, ecological planning, climate responsive design, green roofs and vertical gardens. 


\section{Benchmark Scores}

The parameters of this indicator are derived from the U.S. Environmental Protection Agency (1993, p.46) study, which investigates the changes of evapotranspiration rates resulting from increased impervious surfaces (figure below).

This indicator investigates changes in evapotranspiration resulting from impervious surfaces. Evapotranspiration is a collective term which comprises transpiration from urban vegetation and evaporation from wet pervious and impervious surfaces. The impervious surface ratio is calculated by dividing the total impervious surfaces in a parcel by the total parcel area, as shown below:

$$
I S R=\frac{I A_{\text {total }} * 100}{A_{\text {Total area }}}
$$

Where: $I A_{\text {total }}$ is the total impervious area within parcel, $A_{\text {Total area }}$ is the total parcel area.

\section{Indicator 2 Surface Runoff

Calculation \\ Surface runoff rate for each parcel is calculated based on the 'composite runoff coefficient' formula, which has been used in a number of studies in the literature (Caltrans, 2001; ODOT, 2005; Nicklow et al., 2006; City of Springfield, 2007). The runoff coefficient (C) is defined as the $\%$ of rainfall that becomes runoff. Composite runoff coefficient is generated by multiplying each surface type by its coefficient and then dividing the sum of these results by the total parcel area, as shown below:

$$
C_{\text {com }}=\frac{\sum\left(C_{\text {individual area }}\right)\left(A_{\text {individual area }}\right)}{A_{\text {total area }}}
$$

Where: $C_{\text {individual area }}$ is the runoff coefficient of each surface type, $A_{\text {individual area }}$ is the area of each surface type within parcel, and $A_{\text {total area }}$ is the total parcel area.

\begin{tabular}{|l|l|l|l|}
\hline Type of Surfaces & Ranges & $\begin{array}{l}\text { Runoff } \\
\text { Coefficients }\end{array}$ & References \\
\hline Tree cover & $0.06-0.20$ & 0.13 & Lindeburg (1994) \\
\hline Grass & $0.05-0.35$ & 0.20 & ASCE/WEF (1992) \\
\hline Barren soil & $0.35-0.45$ & 0.40 & ASCE/WEF (1992) \\
\hline Driveway/walkway/cycleway & $0.75-0.85$ & 0.80 & Lindeburg (1994) \\
\hline $\begin{array}{l}\text { Pavement(asphalt, concrete, } \\
\text { brick) }\end{array}$ & $0.70-0.95$ & 0.83 & ASCE/WEF (1992) \\
\hline Roof & $0.75-0.95$ & 0.85 & ASCE/WEF (1992) \\
\hline
\end{tabular}

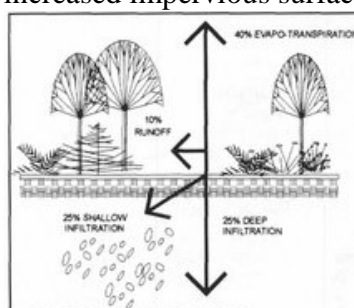

NATURAL GROUND COVER

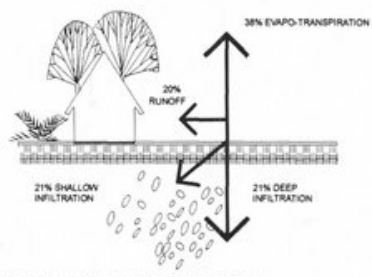

10-20\% IMPERVIOUS SURFACE
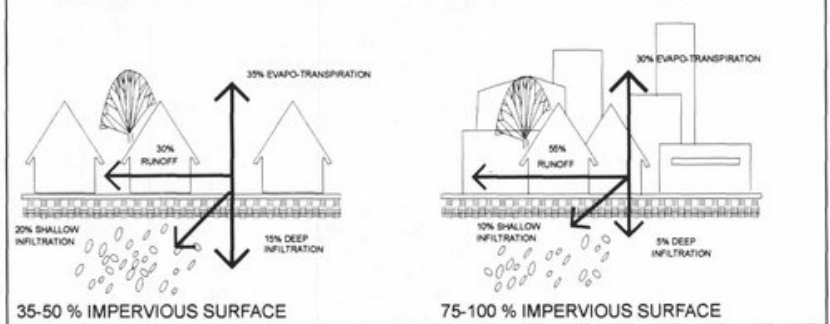

Benchmark values are assigned as shown below.

\begin{tabular}{|l|l|l|}
\hline $\begin{array}{l}\text { Evapotranspiration } \\
\text { Rate (\%) }\end{array}$ & $\begin{array}{l}\text { Impervious Surface } \\
\text { Ratio (\%) }\end{array}$ & Benchmark Value \\
\hline 40 & 0 (Natural Ground cover) & HIGH \\
\hline 39 & $1-15$ & MEDIUM-HIGH \\
\hline 37 & $16-43$ & MEDIUM \\
\hline 33 & $44-88$ & MEDIUM-LOW \\
\hline 30 & $89-100$ & LOW \\
\hline
\end{tabular}

Limitation: In their study, the U.S. Environmental Protection Agency calculated evapotranspiration rates under four categories-natural ground cover, $10-20 \%$ impervious surface, $35-50 \%$ impervious surface and $75-100 \%$ impervious surface. However, impervious surface ratios are not contiguous. Therefore, five reference levels are assigned by taking the arithmetic mean of these evapotranspiration rates and impervious surface ratios.

\section{Unit: \% \\ Benchmark Scores}

Benchmark scores derived from Markart et al. (2006) are assigned as shown below.

\begin{tabular}{|l|l|}
\hline Surface Runoff Ratio (\%) & Benchmark Value \\
\hline$<10$ & HIGH \\
\hline $11-30$ & MEDIUM-HIGH \\
\hline $31-50$ & MEDIUM \\
\hline $51-75$ & MEDIUM-LOW \\
\hline $75<$ & LOW \\
\hline
\end{tabular}




\title{
Appendix 1. Description of indicators
}

\section{Appendix 1. Cont'd}

\author{
$1^{\text {st }}$ Category: Natural environment \\ Indicator 3 Green Area Ratio \\ Calculation \\ The green area ratio is based on the calculation of the \\ crown area of existing trees and shrubs as well as low \\ lying vegetation. Green area ratio for each parcel is \\ calculated by dividing the total green area in a parcel by \\ the total parcel area, as shown below:

$$
G A R=\frac{G A_{\text {Total area }}}{A_{\text {total area }}}
$$ \\ Where: $G A_{\text {Total area }}$ is the total green area within parcel, \\ $A_{\text {total area }}$ is the total parcel area.
}

Unit: \%

Benchmark Scores

Benchmark values derived from Japanese green rating tool CASBEE (2007) are assigned as shown below.

\begin{tabular}{|l|l|}
\hline Green Area Ratio (\%) & Benchmark Value \\
\hline $50<$ & HIGH \\
\hline $41-50$ & MEDIUM-HIGH \\
\hline $31-40$ & MEDIUM \\
\hline $21-30$ & MEDIUM-LOW \\
\hline$<20$ & LOW \\
\hline
\end{tabular}

\begin{tabular}{|l|l|}
\hline Indicator $\mathbf{4}$ & Surface Albedo \\
\hline Calculation & \\
\hline
\end{tabular}

Unit: \%

Benchmark Scores

Albedo, defined by Akbari et al. (1992), is the ability of a surface to reflect incoming solar radiation. Surfaces with low albedo absorb most of the solar energy whereas surfaces with high albedo reflect most of the solar energy. The albedo of different surfaces for each parcel is calculated based on the 'effective albedo' formula derived from the study conducted by Taha et al. (1988). The effective albedo is generated by multiplying each surface type by its albedo value and then dividing the sum of these results by their total area as shown below:

$$
E A=\frac{\sum\left(A_{i} * \propto_{i}\right)}{\sum A_{i}}
$$

Where: $A_{i}$ is the area of each surface type within parcel, $\propto_{i}$ is the albedo value of each surface type.

The albedo values for each surface type are:

\begin{tabular}{|l|l|l|l|}
\hline Type of Surfaces & Ranges & Averages & References \\
\hline Roads (driveway/cycleway) (asphalt) & $0.05-020$ & 0.13 & $\begin{array}{l}\text { Oke (1978), Akbari et } \\
\text { al. (1992) }\end{array}$ \\
\hline $\begin{array}{l}\text { Water surface (solar altitude between } \\
>10^{\circ} \mathrm{C} \text { and }>45^{\circ} \mathrm{C} \text { ) }\end{array}$ & $0.05-0.22$ & 0.14 & $\begin{array}{l}\text { German Solar Energy } \\
\text { Society (2008) }\end{array}$ \\
\hline Barren soil & 0.17 & 0.17 & $\begin{array}{l}\text { Oerman Solar Energy } \\
\text { Society (2008) }\end{array}$ \\
\hline Pavement & $0.15-0.25$ & 0.20 & Akbari et al. (2009) \\
\hline Building & $0.10-0.35$ & 0.23 & Taha et al. (1988) \\
\hline Deciduous Forest & $0.10-0.20$ & 0.15 & Akbari et al. (1992) \\
\hline Coniferous Forest & $0.05-0.15$ & 0.10 & Akbari et al. (1992) \\
\hline Grass & $0.25-0.30$ & 0.28 & Akbari et al. (1992) \\
\hline Walkway (concrete) & $0.25-0.40$ & 0.33 & Akbari et al. (2009) \\
\hline
\end{tabular}

As stated by Oke (1978, p. 247), the albedo value of urban surfaces are in the 10-27 range. Therefore, five reference levels are equally assigned in this range, as shown below.

\begin{tabular}{|c|c|c|c|}
\hline Indicator 5 & Air Pollution & \multicolumn{2}{|l|}{ Unit: $\mu \mathrm{g} / \mathrm{m}^{3}$} \\
\hline \multicolumn{2}{|l|}{ Calculation } & \multicolumn{2}{|c|}{ Benchmark Scores } \\
\hline \multirow{6}{*}{\multicolumn{2}{|c|}{$\begin{array}{l}\text { This indicator is calculated based on transport related lead } \\
\text { concentrations in the air. Among the various transport } \\
\text { related pollutants, Lead (Pb) is chosen as the cursor } \\
\text { pollutant. However, another air pollutant can be used } \\
\text { according to the air quality targets of the other case study } \\
\text { areas. }\end{array}$}} & \multicolumn{2}{|c|}{$\begin{array}{l}\text { Benchmark values are assigned in accorda } \\
\text { and standards of air toxics from the Dep } \\
\text { Environment, Water, Population and Com } \\
\text { (DSEWPC, 2001). }\end{array}$} \\
\hline & & \begin{tabular}{|l}
$\begin{array}{l}\text { Pb concentration } \\
\left(\mu \mathrm{g} / \mathrm{m}^{3}\right)\end{array}$ \\
\end{tabular} & Benchmark Value \\
\hline & & $0.000-0.050$ & HIGH \\
\hline & & \begin{tabular}{|l|}
$0.050-0.125$ \\
\end{tabular} & MEDIUM-HIGH \\
\hline & & $0.125-0.250$ & \begin{tabular}{|l|} 
MEDIUM \\
\end{tabular} \\
\hline & & $0.250-0.375$ & MEDIUM-LOW \\
\hline
\end{tabular}

\begin{tabular}{|l|l|}
\hline Effective Albedo (\%) & Benchmark Value \\
\hline $27<$ & HIGH \\
\hline $21.4-27$ & MEDIUM-HIGH \\
\hline $15.7-21.4$ & MEDIUM \\
\hline $10-15.7$ & MEDIUM-LOW \\
\hline$<10$ & LOW \\
\hline
\end{tabular}


Appendix 1. Cont'd

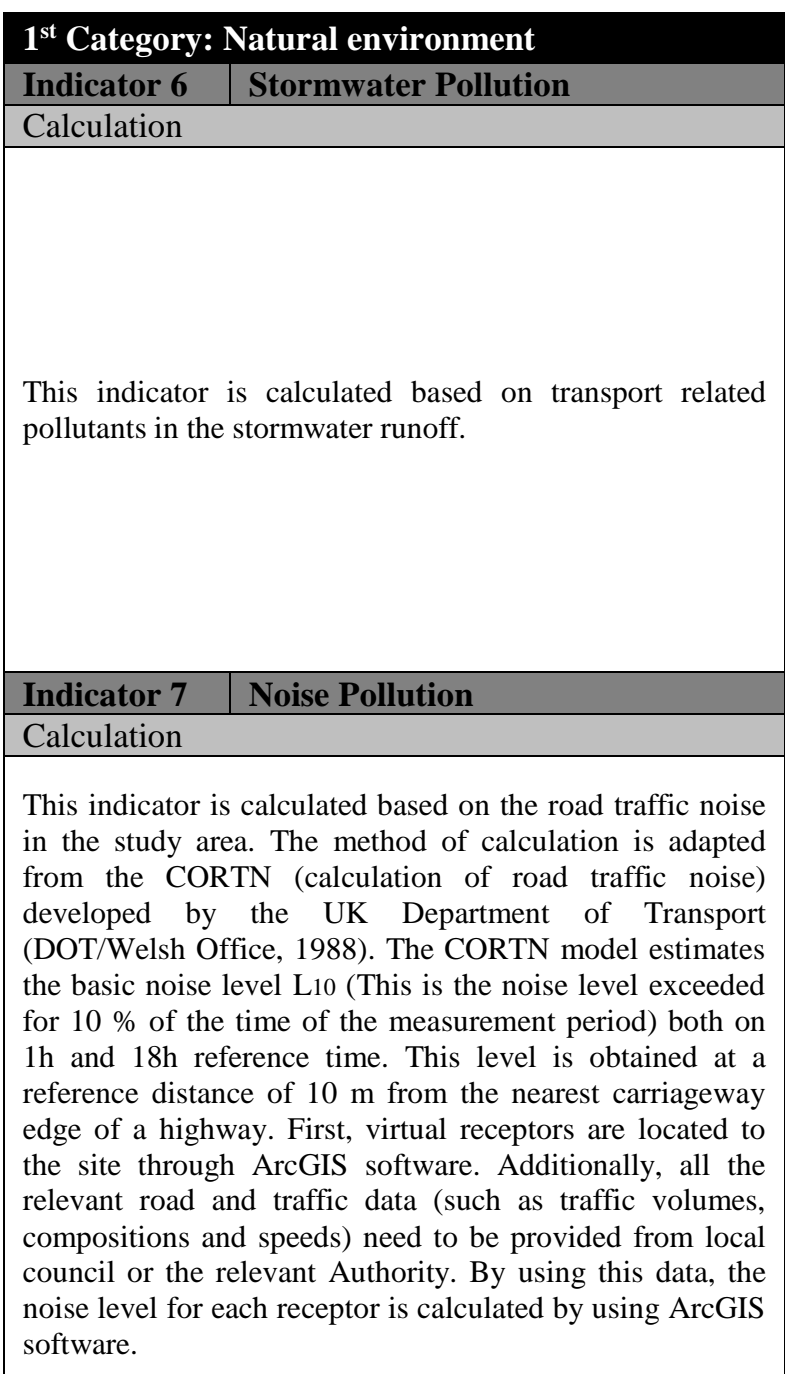

Unit: $\mathrm{mg} / \mathrm{L}$

Benchmark Scores

Benchmark values are derived from water quality standards for drinking, recreational and irrigation advised by National Health and Medical Research Council and the Natural Resource Management Ministerial Council (NHMRC \& NRMMC, 2004).

\begin{tabular}{|l|l|}
\hline Pb concentration $\mathbf{( m g} / \mathbf{L})$ & Benchmark Value \\
\hline $0.00-0.02$ & HIGH \\
\hline $0.03-0.10$ & MEDIUM-HIGH \\
\hline $0.11-0.20$ & MEDIUM \\
\hline $0.21-0.50$ & MEDIUM-LOW \\
\hline $0.51-1.00$ & LOW \\
\hline
\end{tabular}

Limitation: The indicator may need to be changed or modified in the implementation of other case studies according to the available data sources.

\section{Unit: dBA}

Benchmark Scores

Benchmark values derived from Kloth et al. (2008) were assigned as shown below.

\begin{tabular}{|l|l|l|}
\hline $\begin{array}{l}\text { Traffic noise } \\
\text { pollution (dBA) }\end{array}$ & Descriptions & $\begin{array}{l}\text { Benchmark } \\
\text { Value }\end{array}$ \\
\hline$<45$ & $\begin{array}{l}\text { Excellent soundlevel (The threshold } \\
\text { for sleep interference is 45 dBA) }\end{array}$ & HIGH \\
\hline $46-55$ & $\begin{array}{l}\text { Good sound level (55 dBA is the level } \\
\text { of a quiet suburban street) }\end{array}$ & $\begin{array}{l}\text { MEDIUM- } \\
\text { HIGH }\end{array}$ \\
\hline $56-65$ & $\begin{array}{l}\text { Acceptable soundlevel (65 dBA is the } \\
\text { level of nomal conservation) }\end{array}$ & MEDIUM \\
\hline $66-75$ & $\begin{array}{l}\text { Mediocre sound level (75 dBA is the } \\
\text { level of a passenger car) }\end{array}$ & $\begin{array}{l}\text { MEDIUM- } \\
\text { LOW }\end{array}$ \\
\hline $76-90$ & $\begin{array}{l}\text { Harmful soundlevel(90 dBA is the } \\
\text { level of a heavy truck) }\end{array}$ & LOW \\
\hline
\end{tabular}

Limitation: The topography of the area needs to be excluded from the analysis as well as traffic speeds needs to be taken as constant, and the receptor points are need to be considered as same height.

\section{$2^{\text {nd }}$ Category: Built environment}

\begin{tabular}{|l|l|}
\hline Indicator 8 & $\begin{array}{l}\text { Proximity to Land Use } \\
\text { Destinations }\end{array}$ \\
\hline Calculation & \\
\hline
\end{tabular}

Unit: NDAI score

Benchmark Scores

Benchmark values are adapted from the Neighbourhood Destination Accessibility Index (NDAI) developed by Mavoa et al. (2009). The NDAI is a GIS tool that measures the pedestrian access to eight domains of neighbourhood destinations (education, transport, recreation, social and cultural, food retail, financial, health, other retail) within given boundaries (Witten et al., 2011, p. 205). Weightings ranging from 2 to 5 are assigned to each domain based on their relative importance as a catalyst to physical activity (See Appendix 2). The weighted domain scores are then summed to produce a total neighbourhood destination index score (Mavoa et al., 2009, p.16).

\begin{tabular}{|l|l|}
\hline $\begin{array}{l}\text { Access to local services } \\
\text { (NDAI score) }\end{array}$ & Benchmark Value \\
\hline $103-135$ & HIGH \\
\hline $69-102$ & MEDIUM-HIGH \\
\hline $35-68$ & MEDIUM \\
\hline $15-34$ & MEDIUM-LOW \\
\hline $0-14$ & LOW \\
\hline
\end{tabular}

This indicator is calculated based on the accessibility of wicel to land use destinations, which is within $800 \mathrm{~m}$ walking distance by using the Arcd as the local services provided for the residents to visit regularly for their needs, such as shopping, education, recreation and health facilities. As recommended by similar studies (Austin et al., 2005; Algert et al., 2006; Witten et al., 2011), an 800-metre distance is taken as the maximum threshold that residents in the neighbourhood will walk. 


\section{Appendix 1. Cont'd}

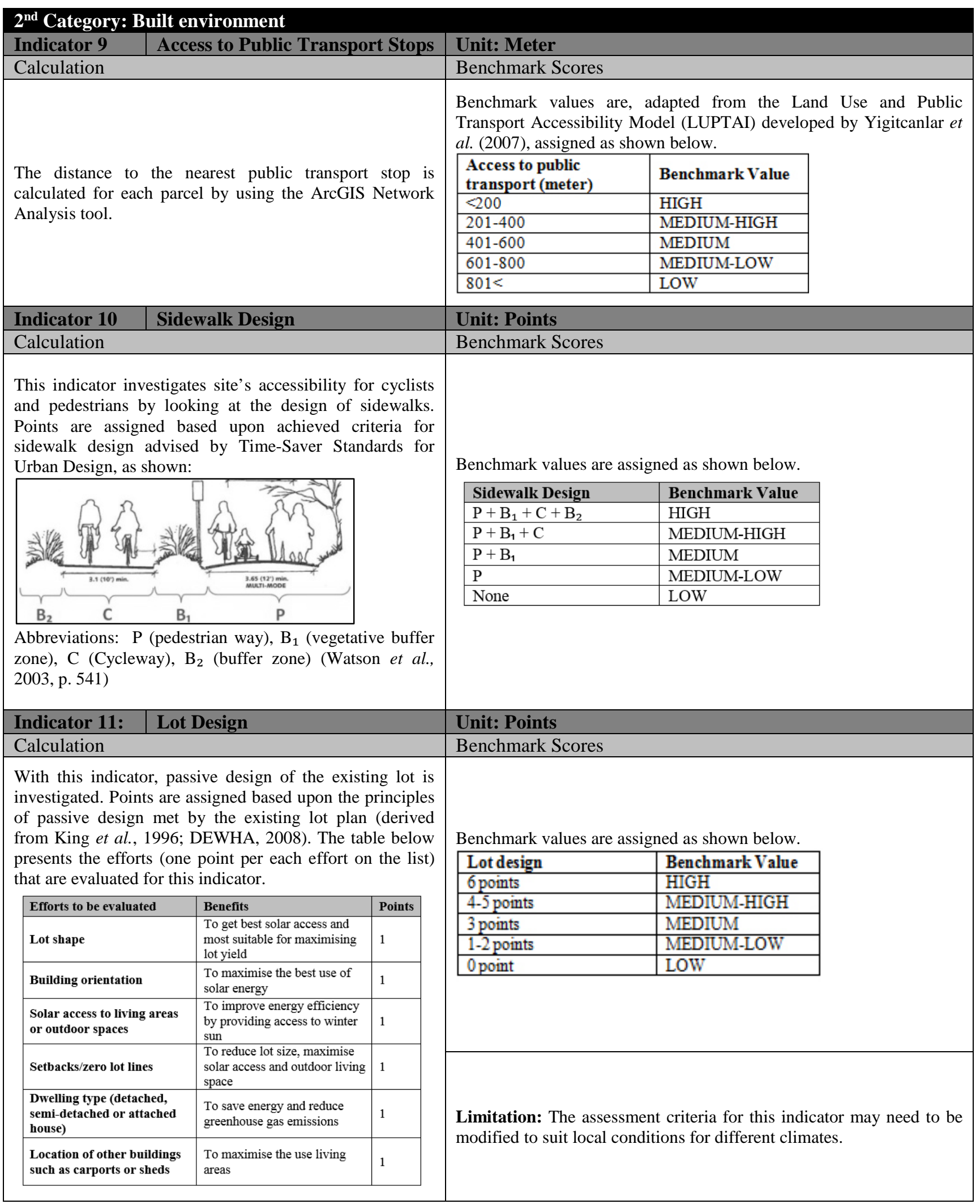


Appendix 1. Cont'd

\section{$2^{\text {nd }}$ Category: Built environment}

\section{Indicator 12: $\quad$ Landscape Design}

Calculation

Points are assigned based upon the principles of climate responsive landscape design met by the existing lot plan. There are different landscaping techniques appropriate for four main climates. Points are given for the efforts taken for planting design of each side around the building below (Lechner, 2009).

Temperate climate:

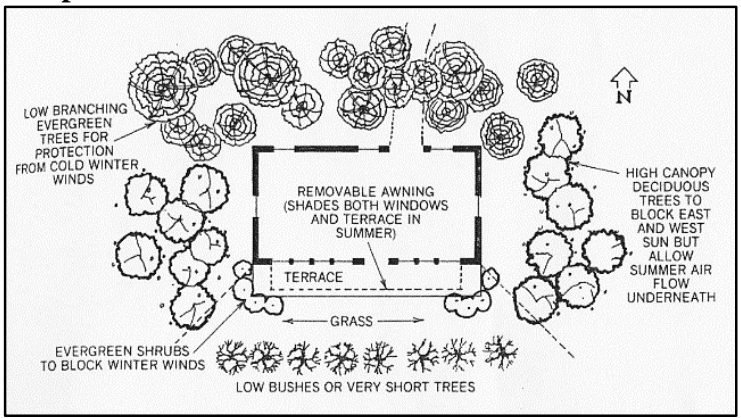

\section{Hot and dry climate:}

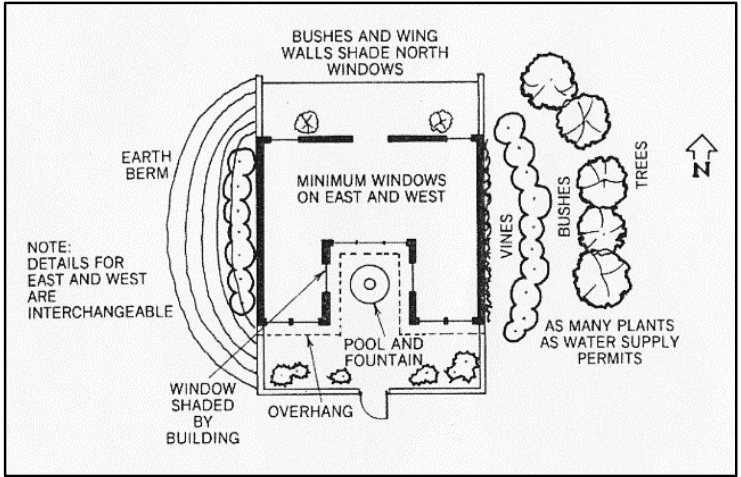

Hot and humid climate:

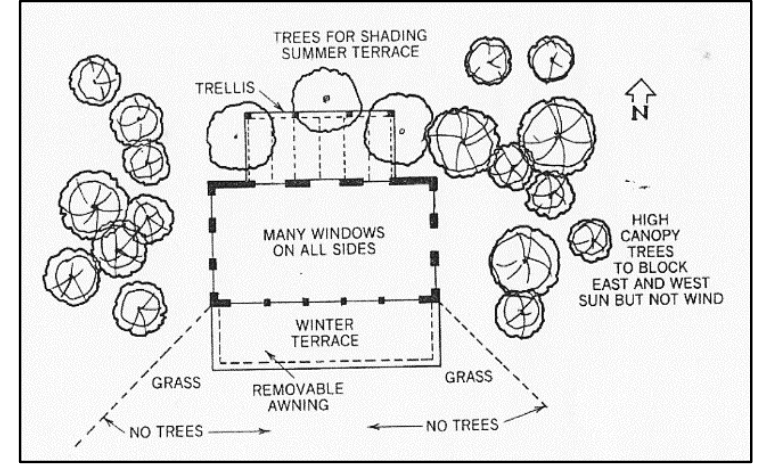

\section{Cold climate:}

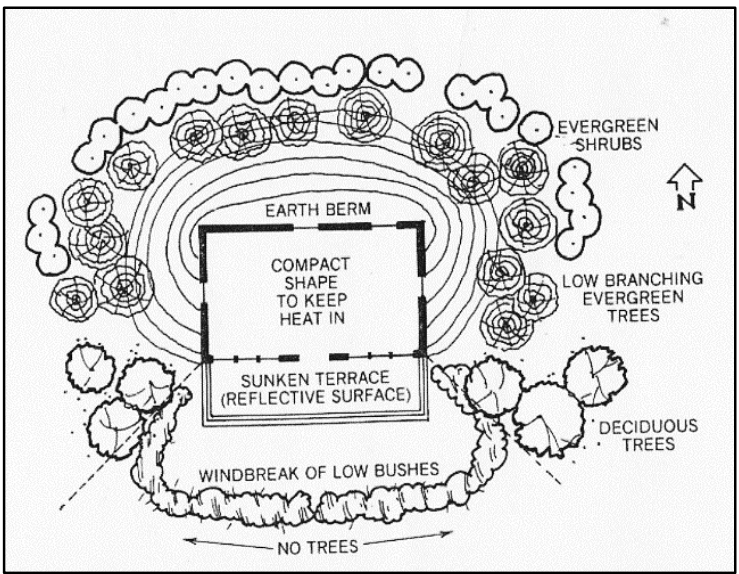

Unit: Points

Benchmark Scores

Benchmark values are assigned as shown below.

\begin{tabular}{|l|l|}
\hline Landscape design & Benchmark Value \\
\hline 4 points & HIGH \\
\hline 3 points & MEDIUM-HIGH \\
\hline 2 points & MEDIUM \\
\hline 1 point & MEDIUM-LOW \\
\hline 0 point & LOW \\
\hline
\end{tabular}

Limitation: The assessment criteria for this indicator may need to be modified to suit local conditions for different climates. 
Appendix 1. Cont'd

$2^{\text {nd }}$ Category: Built environment

\section{Indicator 13: $\quad$ Energy Conservation}

Calculation

With this indicator, annual energy consumption is investigated. Points are assigned based upon the level of annual energy consumption of the household expressed as " $\mathrm{kWh} / \mathrm{m}^{2} /$ year" which is calculated by dividing the annual electricity use by $\mathrm{m}^{2}$ space of the house.
Unit: Points

Benchmark Scores

In France, 5 levels of regulatory requirements for the energy performance of buildings are defined. The BBC (Bâtiment Basse Consommation)-Effinergie label is created jointly with the French Ministry of Housing and the Effinergie association (EFFINERGIE, 2008). Benchmark values are assigned as shown below.

\begin{tabular}{|l|l|}
\hline $\begin{array}{l}\text { Energy consumption } \\
\left(\mathbf{k W h} / \mathbf{m}^{2} / \text { year }\right)\end{array}$ & Benchmark Value \\
\hline$<50$ & HIGH \\
\hline $51-150$ & MEDIUM-HIGH \\
\hline $151-330$ & MEDIUM \\
\hline $331-450$ & MEDIUM-LOW \\
\hline$>450$ & LOW \\
\hline
\end{tabular}

Limitation: Household energy usage data is one of the essential parameters required for defining energy efficiency. However, under some conditions, this data may not be provided due to privacy issues.

\begin{tabular}{|c|c|c|}
\hline Indicator 14: & \multicolumn{2}{|c|}{ Renewable Energy } \\
\hline \multicolumn{3}{|l|}{ Calculation } \\
\hline \multicolumn{3}{|c|}{$\begin{array}{l}\text { With this indicator, use of renewable energ } \\
\text { investigated. Points are assigned based upon } \\
\text { energy systems implemented in the existing } \\
\text { Points are given for the efforts taken for the } \\
\text { renewable energy systems below. }\end{array}$} \\
\hline \multicolumn{2}{|c|}{ Efforts to be evaluated } & Points \\
\hline \multicolumn{2}{|l|}{ Solar panels } & 1 \\
\hline \multicolumn{2}{|l|}{ Rainwater tank } & 1 \\
\hline \multicolumn{2}{|c|}{ Roof-mounted wind turbine } & 1 \\
\hline \multicolumn{2}{|l|}{ Green roof } & 1 \\
\hline
\end{tabular}

\section{Unit: Points}

Benchmark Scores

\section{re} investigated. Points are assigned based upon the renewable energy systems implemented in the existing parcel plan. Points are given for the efforts taken for the installation of renewable energy systems below.

Benchmark values are assigned as shown below.

\begin{tabular}{|l|l|}
\hline Renewable energy & Benchmark Value \\
\hline 4 points & HIGH \\
\hline 3 points & MEDIUM-HIGH \\
\hline 2 points & MEDIUM \\
\hline 1 point & MEDIUM-LOW \\
\hline 0 point & LOW \\
\hline
\end{tabular}


Appendix 1. Cont'd

\begin{tabular}{|c|c|}
\hline Household Type & \\
\hline Description & Categories \\
\hline $\begin{array}{l}\text { This indicator refers to the types of grouping of persons } \\
\text { and living arrangements found in a household. }\end{array}$ & $\begin{array}{l}\text { A. One family households } \\
\text { - Couple family with children } \\
\text { - } \quad \text { Couple family without children } \\
\text { 1. Fone-parent family } \\
\text { 2. Male lone parent } \\
\text { B. Two or more family households } \\
\text { C. Non-family households } \\
\text { - One person households } \\
\text { - Two person households } \\
\text { - Three or more person households }\end{array}$ \\
\hline Indicator 16 & \\
\hline Description & Categories \\
\hline $\begin{array}{l}\text { This indicator refers to the age distribution of the } \\
\text { household members. }\end{array}$ & 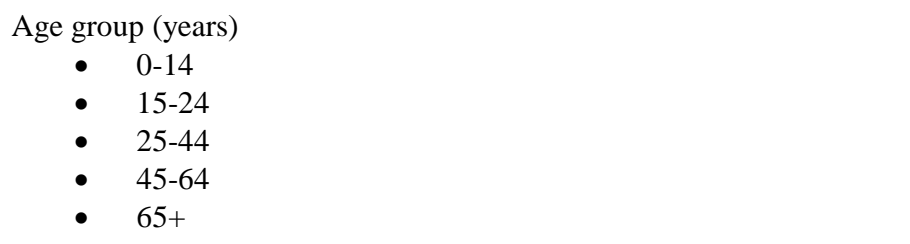 \\
\hline Immigration status & \\
\hline Description & Categories \\
\hline $\begin{array}{l}\text { This indicator refers to the immigration status of the } \\
\text { persons in the household. }\end{array}$ & $\begin{array}{l}\text { This indicator is represented by two variables derived from a study } \\
\text { conducted by Luck et al (2009): } \\
\text { - } \quad \text { Persons, in the household, not born in the country } \\
\text { - Persons, in the household, arriving in the country in the last } \\
10 \text { years }\end{array}$ \\
\hline Equivalised household income & \\
\hline Description & Categories \\
\hline $\begin{array}{l}\text { This indicator refers to the total income (per week) of a } \\
\text { household divided by the number of households converted } \\
\text { into equalised adults. }\end{array}$ & $\begin{array}{l}\text { Households are equalised by weighting each according to their age, } \\
\text { using the OECD equivalence scale: } \\
\text { - } 1 \text { to the first adult; } \\
\text { - } 0.5 \text { to the second and each subsequent person aged } 14 \text { and } \\
\text { over; } \\
0.3 \text { to each child aged under } 14 \text {. }\end{array}$ \\
\hline \multicolumn{2}{|l|}{\begin{tabular}{l|l} 
Indicator 19 & Employment Status \\
\end{tabular}} \\
\hline Description & Categories \\
\hline $\begin{array}{l}\text { This indicator refers to the employment status of the } \\
\text { households. }\end{array}$ & $\begin{array}{ll}\text { - } & \text { Self-employed } \\
\text { - } & \text { Employed (Full time/Part time) } \\
\text { - } & \text { Not employed } \\
\text { - } & \text { Student } \\
\text { - } & \text { Retired } \\
\text { - } & \text { Unable to work }\end{array}$ \\
\hline \multicolumn{2}{|l|}{\begin{tabular}{l|l} 
Indicator 20 & Level of Education \\
\end{tabular}} \\
\hline Description & Categories \\
\hline This indicator refers to the educational level of households. & $\begin{array}{l}\text { - } \quad \text { Less than high school } \\
\text { - High school } \\
\text { - } \quad \text { University/College } \\
\text { - } \quad \text { Master's degree and higher } \\
\text { Did not go to school }\end{array}$ \\
\hline
\end{tabular}


Appendix 1. Cont'd

$3^{\text {rd }}$ Category: Socio-Economic environment

Indicator 21 Car Ownership

\begin{tabular}{|l|l}
\hline Description & Categories
\end{tabular}

This indicator refers to the number of cars in the households.

- Having a single car

- Having more than one car

- Not having a car

\section{Indicator 22 Home Ownership}

\begin{tabular}{l|l}
\hline Description & Categories
\end{tabular}

This indicator refers to the households living in their own home.

- $\quad$ Owned by someone in the household

- $\quad$ Rented

\begin{tabular}{l|l|l|}
\hline Indicator 23 & Dwelling Type \\
\hline Description & Categories \\
\hline & $\begin{array}{l}\text { - Single-detached house } \\
\text { This indicator refers to the physical configuration of the } \\
\text { dwelling. }\end{array}$ \\
& $\begin{array}{l}\text { - Semi-detached house } \\
\end{array}$
\end{tabular}

Appendix 2.Neighbourhood destination accessibility index (NDAI) domain weightings

\begin{tabular}{|c|c|c|c|}
\hline Domain/sub-domain & Data type & $\begin{array}{l}\text { Maximum } \\
\text { sub-domain score }\end{array}$ & Weighting score \\
\hline \multicolumn{4}{|l|}{ 1. Education } \\
\hline Kindy/daycare/playcentres & Binary & 1 & \\
\hline Primary schools & Binary & 1 & \\
\hline $\begin{array}{l}\text { Intermediate/full primary } \\
\text { schoo/s }\end{array}$ & Binary & 1 & \\
\hline Secondary schools & Binary & 1 & \\
\hline Total & & 4 & 4 \\
\hline \multicolumn{4}{|l|}{ 2. Transport } \\
\hline Bus stops \& train stations & Tertile & 3 & 5 \\
\hline \multicolumn{4}{|l|}{ 3. Recreation } \\
\hline Accessible green space & Tertile & 3 & \\
\hline Sports facilities & Tertile & 3 & \\
\hline Beaches & Tertile & 3 & \\
\hline Total & & 9 & 5 \\
\hline \multicolumn{4}{|l|}{ 4. Social \& Cultural } \\
\hline Museums/art galleries & Binary & 1 & \\
\hline Public Itbraries & Binary & 1 & \\
\hline Churches & Binary & 1 & \\
\hline Cinemas & Binary & 1 & \\
\hline Community halls/centres & Binary & 1 & \\
\hline Marae & Binary & 1 & \\
\hline Cafes and restaurants & Binary & 1 & \\
\hline \multirow{2}{*}{$\begin{array}{l}\text { Alcohol outlets (hotels, } \\
\text { tavems, clubs, bottle stores) } \\
\text { Total }\end{array}$} & Binary & 1 & \\
\hline & & 8 & 3 \\
\hline \multicolumn{4}{|l|}{ 5. Food retail } \\
\hline Supermarkets & Binary & 1 & \\
\hline Convenience stores/dairies & Binary & 1 & \\
\hline Petrol Stations & Binary & 1 & \\
\hline Fast food outlets & Binary & 1 & \\
\hline Butchers \& Fishmongers & Binary & 1 & \\
\hline Bakeries & Binary & 1 & \\
\hline Greengrocers & Binary & 1 & \\
\hline $\begin{array}{l}\text { Total } \\
\text { Tols }\end{array}$ & & 7 & 5 \\
\hline \multicolumn{4}{|l|}{ 6. Financial } \\
\hline Banks, Credit Unions \& & Binary & 1 & \\
\hline $\begin{array}{l}\text { ATMs } \\
\text { Post offices }\end{array}$ & Binary & 1 & \\
\hline Total & & 2 & 3 \\
\hline \multicolumn{4}{|l|}{ 7. Health } \\
\hline General practtioners & Binary & 1 & \\
\hline $\begin{array}{l}\text { Pharmacies } \\
\text { Pluteis }\end{array}$ & Binary & 1 & \\
\hline Plunket & Binary & 1 & \\
\hline Total & & 3 & 2 \\
\hline \multicolumn{4}{|l|}{ 8. Other Retail } \\
\hline Shopping centres/malls & Binary & 1 & \\
\hline Video shop & Binary & 1 & \\
\hline Retail - Op Shop & Binary & 1 & \\
\hline Total & & 3 & 4 \\
\hline
\end{tabular}




\section{References}

Akbari, N., Davis, S., Dorsano, S., Huang, J., Winnett, S. (Eds.), 1992. Cooling Our Communities: A Guidebook on Tree Planting and Light-Colored Surfacing. USEPA, Washington, DC.

Algert, S., Agrawal, A., Lewis, D., 2006. Disparities in access to fresh produce in low-income neighborhoods in Los Angeles. Am. J. Prev. Med. 30, 365-370.

Austin, S., Melly, S., Sanchez, B., Patel, A., Buka, S., Gortmaker, S., 2005. Clustering of fast-food restaurants around schools: a novel application of spatial statistics to the study of food environments. Am. J. Public Health 95, 1575-1581.

ASCE/WEF (Water Environment Federation and American Society of Civil Engineers), 1992f. Design and Construction of Urban Storm water Management Systems, ASCE Manuals and Reports of Engineering Practice No. 77, WEF Manual of Practice FD-20. WEF and ASCE, Reston, VA.

BREEAM, 2006. Ecohomes 2006 — The Environmental Rating for Homes — The Guidance, UK Foundation for the Built Environment, Building Research Establishment Environmental Assessment Method. Retrieved October 15, 2011, from http://www.breeam.org/filelibrary/Technical\%20Manuals/EcoHomes_2006_Guidance_v1.2__April_2006.pdf.

Caltrans (California Department of Transportation) (2001). Highway design manual, Chapter 810Hydrology, Sacramento, CA, Retrieved April 15, 2012, from http://www.dot.ca.gov/hq/oppd/hdm/pdf/chp0810.pdf

CASBEE, 2007. Comprehensive Assessment System for Building Environmental Efficiency for Urban Development-Technical Manual, Japan Sustainable Building Consortium (JSBC)/Japan GreenBuild Council (JaGBC). Retrieved October 15, 2011, from http://www.ibec.or.jp/CASBEE/english/index.htm.

City of Springfield, 2007. Springfield Storm Drainage Criteria Manual. Retrieved April 15, 2012, from http://www.springfieldmo.gov/stormwater/pdfs/Criteria/Chapter5.pdf.

De Ridder, W., 2006. Tool Use in Integrated Assessments: Integration and Synthesis Report for the Sustainability-A Test Project, Mnp-Report 550030001/2006. Netherlands Environmental Assessment Agency (MNP), Bilthoven, The Netherlands.

DEWHA (Department of the Environment, Water, Heritage and the Arts), 2008A. Your Home Technical Manual - Fourth Edition. Retrieved April 15, 2012, from http://www.yourhome.gov.au/technical/fs41.html.

DOT/Welsh Office, 1988. Calculation of Road Traffic Noise. HMSO, London.

EFFINERGIE, 2008. Low-Consumption Building: The Achievement of a Project, Paris. Retrieved May 9, 2015, from http://www.effinergie.org/web/images/association/english/GuideEffinergieEnglishV2.pdf.

HK-BEAM, 2004a. An Environmental Assessment Method for New Buildings. Hong Kong Building Environmental Assessment Method Society Retrieved October 15, 2011, from http://www.beamsociety.org.hk/fileLibrary/_404\%20New\%20Buildings\%20(Full\%20Version).pdf?PHPSES $\mathrm{SID}=627727059 \mathrm{~d} 8 \mathrm{a} 83 \mathrm{~d} 20 \mathrm{c} 77 \mathrm{cfa} 162 \mathrm{ae} 06 \mathrm{f} 8$.

King, S., Rudder, D., Prasad, D., Ballinger, J., 1996. Site planning in Australia. Strategies for Energy Efficient Residential Planning. AGPS, Canberra.

Kinzig, A.P., Warren, P., Martin, C., Hope, D., Katti, M., 2005. The Effects of Human Socio-economic Status and Cultural Characteristics on Urban Patterns of Biodiversity, Ecology and Society. Retrieved May 25, 2010, from http://www.ecologyandsociety.org/ 617 vol10/iss1/art23/. 
Kloth, M., Vancluysen, K., Clement, F., 2008. Practitioner Handbook for Local Noise Action PlansRecommendations From the SILENCE Project. AVL List GmbH, Austria.

Lechner, N., 2009. Heating, Cooling, Lighting, Sustainable Design Methods for Architects Wiley.

Lindeburg, M.R., 1994. Civil Engineering Reference Manual. 9th ed. Professional Publications, Inc., Belmont, CA, pp. 6-24.

Markart, G., Kohl, B., Kirnbauer, R., Pirkl, H., Bertle, H., Stern, R., et al., 2006. Surface runoff in a torrent catchment area in middle Europe and its prevention. Geotech. Geol. Eng. 24, 1403-1424.

Mavoa, S., Witten, K., Pearce, J., Day, P., 2009. Measuring Neighbourhood Walkability in New Zealand Cities. Centre for Social and Health Outcomes Research and Evaluation, Massey University, Auckland.

NHMRC, NRMMC, 2004b. Australian Drinking Water Guidelines 2004. National Water Quality Management Strategy. National Health and Medical Research Council and the Natural Resource Management Ministerial Council.

Nicklow, J.W., Boulos, P.F.,Muleta,M.K., 2006. Comprehensive Urban Hydrological Modeling Handbook for Engineers and Planners. MWH Soft Publ., Pasadena, CA.

ODOT, 2005. Hydraulics Manual. Oregon Department of Transportation Retrieved April 15, 2012, from ftp://ftp.odot.state.or.us/techserv/Geo-

Environmental/Hydraulics/Hydraulics\%20Manual/Chapter_07/Chapter_07_appendix_F/CHAPTER_07_app endix_F.pdf.

Oke, T.R., 1978. Boundary Layer Climates. Methuen, London.

Taha, H., Akbari, H., Rosenfeld, A., 1988. Residential cooling loads and the urban heat island: the effects of albedo. Build. Environ. 23, 271-283.

U.S. Environmental Protection Agency, 1993. Guidance Specifying Management Measures for Sources of Nonpoint Pollution in CoastalWaters, EPA 840-B-92-002. Environmental Protection Agency, Office of Water, Washington, DC.

U.S. Green Building Council, 2005. LEED for Neighbourhood Developments Rating System Preliminary Draft. U.S. Green Building Council Retrieved October 15, 2011, from https://www.usgbc.org/ShowFile.aspx?DocumentID=959.

Watson, D., Plattus, A.J., Shibley, R.G., 2003. Time-saver Standards for Urban Design. McGraw-Hill, New York

Witten, K., Pearce, J., Day, P., 2011. Neighbourhood destination accessibility index: a GIS tool for measuring infrastructure support for neighbourhood physical activity. Environ. Plan. A 43, 205-223.

Yigitcanlar, T., Sipe, N.G., Evans, R., Pitot, M., 2007. A GIS-based land use and public transport accessibility model. Australian Planner 44 (3), 30-37. 